\title{
Relation between Activator Factors and Compliance Behavior of Using Personal Protective Equipment on Technician Workers at PT ARPS Surabaya
}

\section{Hubungan antara Faktor Activator dengan Perilaku Kepatuhan Penggunaan Alat Pelindung Diri Pada Pekerja Teknisi PT ARPS Surabaya}

\author{
Mu'afiah $^{1}$, M. Misbakhul Munir ${ }^{2}$, Indriati Paskarini ${ }^{3}$ \\ ${ }^{1,3}$ Department of Occupational Safety and Health, Faculty of Public Health, Universitas Airlangga \\ Campus C Mulyorejo, Surabaya, East Java 60115, Indonesia \\ ${ }^{2}$ Wilmar International Limited - PT. Rimba Harapan Sakti \\ Pematang Limau Village, Seruyan Hilir, Seruyan District, Central Kalimantan 74213, Indonesia
}

\begin{abstract}
Introduction: Equipment that must be used by workers for work safety when working with potential work hazards or accidents is personal protective equipment (PPE). The purpose of this study was to analyze the factors associated with the use of PPE in the workforce of technicians at PT. APRS in terms of PPE usage. Methods: This research was an analytic observational study, with cross sectional design. The subjects of this study were all of the technician workforce in the section of Blow molding, Maintenance and Injection Molding unit, totalling 39 respondents. Results: This study showed that activator factors such as perception $(r=0.108)$, knowledge of occupational health and safety $(r=-0.104)$, and PPE regulation $(\mathrm{r}=-0.166)$ had a weak relationship with safety behavior on compliance with PPE implementation. Conclusions: The workforce behaved poorly in using PPE in the workplace. In the Blow Molding, Maintenance and Injection Molding unit, workers who had a moderate level of perceptions, workers who had a moderate level of knowledge, and workers who had a enough ability to comply with PPE regulations.
\end{abstract}

Keywords: knowledge, perception, personal protective equipment, policy

\section{ABSTRAK}

Pendahuluan: Peralatan yang wajib dipakai untuk melindungi dan menjaga keselamatan tenaga kerja saat bekerja dengan potensi bahaya atau resiko kecelakaan kerja adalah alat pelindung diri (APD). Tujuan penelitian ini adalah menganalisa faktor yang berhubungan dengan perilaku penggunaan APD pada tenaga kerja teknisi di PT. APRS dalam perilaku kepatuhan penggunaan APD. Metode: Penelitian ini bersifat observasional analitik, dengan desain cross sectional. Subjek penelitian ini adalah seluruh tenaga kerja teknisi pada bagian blow molding, maintenance dan injection molding sebesar 39 responden. Hasil: Penelitian ini menunjukkan bahwa faktor aktivator yaitu persepsi ( $r=$ 0,108), pengetahuan $K 3(r=-0,104)$, dan peraturan APD adalah $(r=-0,166)$ memiliki hubungan lemah dengan perilaku keselamatan pada kepatuhan dengan penerapan APD. Simpulan: Pekerja berperilaku buruk dalam menggunakan APD di tempat kerja, untuk pekerja di unit blow molding, maintenance dan injection molding menunjukkan pekerja memiliki persepsi yang cukup baik dan pekerja memiliki pengetahuan yang cukup baik serta pekerja memiliki kemampuan yang cukup baik terhadap peraturan APD.

Kata kunci: alat pelindung diri, kebijakan, pengetahuan, persepsi

Corresponding Author:

Mu'afiah

Email: muafiah-2016@fkm.unair.ac.id

Telephone: +6289613078027

\section{INTRODUCTION}

There has been a rising concern on the development of occupational safety and health in the industrial sector in Indonesia. This certainly causes a big change in the industrial sector, where industries use more technology from input, process to output in the form of goods or services. The changes that occur certainly have benefits as well as give rise to the potential danger of work accidents if not handled and controlled to the maximum. 
The incidence of accidents and occupational diseases has caused 2.78 million workers die every year (International Labour Organization, 2018). The increase in deaths due to occupational diseases was around 2.4 million (86.3\%), while around 380,000 $(13.7 \%)$ were caused by workplace accidents (International Labour Organization, 2018). In addition to causing untold human suffering, accidents and occupational diseases result in significant economic costs, with an estimated annual loss of 3.94 percent of global GDP. According to Hashim and May (2018) around 2 million people around the world were laid off from work because they were spared, of which $25 \%$ or more experiencing head, eye, hand and foot injuries. Factors that cause this to happen are a lack of knowledge and use of safety equipment.

Seeing the high number of work accidents, a control hierarchy must be made consisting of elimination, substitution, technical control, administrative control, PPE,expanded with welfare and monitoring (Uzun et al., 2018). Risk control through environmental safeguards tools and techniques are things that must be prioritized, but the fact that occursis that sometimes work risks cannot be controlled. Therefore, the management must provide a solution, one of which is by requiring the use of PPE for the workforce.

PPE is a protective device for workers used to reduce danger. PPE can be interpreted as a tool used to protect workers from the temperature exposure. The use of PPE is an effective measure to reduce the risk of workplace accidents (Tanko and Anigbogu, 2012). Obligations regarding PPE are not only required for companies as providers, but are also required for workers to be obedient in using PPE in accordance with the potential hazards in the workplace. This has been regulated in the Minister of Manpower and Transmigration Regulation number 8 of 2010 concerning PPE article 6 paragraph 1 . However, the fact in the field indicates that the level of compliance using PPE is still low. The underlying factor is the level of perception of labors who consider that PPE can interfere with their work. Research that has been done by Barizqi (2015) found that $36.4 \%$ of workers who were not compliant to use PPE experienced a work accident in the form of falling while working on the project, $42.4 \%$ of workers experienced a work accident in the form of being struck down or falling down during work in a construction project, $18.2 \%$ of workers had a work accident in the form of being pinched, $15.2 \%$ of workers had an accident in the form of the use of hammer, and $0.33 \%$ of workers had a work accident in the form of a sharp object being scratched. There were even workers who experienced more than one type of work accident.

Based on this, an approach is needed to be able to change the behavior of the workforce. The process of changing behavior can be carried out systematically and objectively by identifying and strengthening one's attitude to be able to behave safely in the workplace, as well as manipulating the conditions of the work environment by implementing security, safety and welfare of the workforce. Behavior Based Safety (BBS) is an occupational safety program that focuses on the behavior of safety workers (Safety Behavior) where workers can determine the tools and procedures that can be used to control individuals to avoid work risks (Geller, 2005).

PT APRS, as the research site of this study, is a company engaged in manufacturing plasticbased products as cosmetic packaging products and equipment products for daily needs. The main production process of making packaging on ARPS is done by the means of injection of hot plastic (Injection) and blowing of hot plastic dough (Blow Molding) with plastic seed raw material. The routine work of technicians in the Injection and Blow Molding section is to prepare the machine before production (Star-Up), supervise and regulate the machine during the production process and dismantle and maintain the machine when it is not in production. All of the work done definitely has a lot of types of potential hazards, both physical and potential chemical hazards, such as electric shock, heat radiation (temperature $>2000 \mathrm{C}$ ), fire or explosion, noise, dust exposure, and possibility of being crushed, impacted, imprinted by the remaining molds. This is exacerbated by workers' non-compliance with the use of PPE as a factor for unsafe action. Thus, the researchers in this study will analyze worker activator factors associated with worker compliance behavior with the use of PPE on technicians in the Injection and Blow Molding section.

The method that can be used to consider a person's behavior is to use the ABC (ActivatorBehavior-Consequence) approach (Geller, 2006). Activator is a signal and a supporter of the emergence of a Behavior, while Consequence is a thing that follows someone after behaving or as a result of the behavior carried out by someone. This principle is used to improve performance in organizations (Geller, 2006) (Wang et al., 2018). 
Based on this, the identification of the factors that underlie employee compliance in using PPE will be carried out with a behavior-based analysis using the activator approach. The aim of this study is to analyze factors that can influence the workforce at PT. APRS in applying the disciplinary behavior in using PPE in the workplace.

\section{METHODS}

This type of research was observational analytic research with cross sectional research method. Cross Sectional Assessment is a type of research that prioritizes. The independent variables in this study were the variables of knowledge, perceptions and regulations related to PPE, while the dependent variable in this study was the behavior of compliance with PPE.

The study was conducted in November 2017 to April 2018 at PT. ARPS located at Jalan Rungkut Industri IV No.23, Rungkut Tengah, Gunung Anyar, Surabaya City. The population of this study was all workers in PT. APRS working as blow molding, maintenance and injection molding technicians totaling 39 workers. Sampling in this study was total sampling, which is a sampling technique where the number of samples is equal to the population (Sugiyono, 2017).

This study used primary data and secondary data. Primary data were obtained through distributing questionnaires that had been tested for validity and reliability, conducting in-depth interviews and making field observations. Meanwhile, secondary data were sourced from a number of literatures in the form of company documents regarding SOP policy on the use of PPE, company's OSH regulations, company profile and staffing data. The data that had been collected were analyzed bivariately and univariately.

Afterwards, the analysis of univariate data was conducted to see the frequency distribution of data and the percentage of each variable studied using the activator. The research data that had been processed were then analyzed using the Spearman correlation test.

\section{RESULTS}

\section{Activator Factor Component}

Activator factor components in the study included knowledge of workers about PPE and occupational health and safety (OHS) in general, workers' perceptions about the risks of hazards in the workplace, and the workers' opinion of PPE regulations.

Based on the activator factor distribution data on 39 respondents of the Blow Molding, Maintenance and Injection Molding section at PT ARPS, the results show that $97.4 \%$ of respondents had good knowledge about PPE and knowledge of OHS, $64.1 \%$ of respondents had a good perception of the risk of accidents and hazards from not using PPE, and $61.5 \%$ of respondents had a good opinion of company regulations in support of PPE usage behavior. From Table 1, it can also be seen that the level of labor knowledge of PPE, perception, and regulation factors was good, although there were still many workers who had a low level of perception and understanding of regulations.

Based on the data on the frequency distribution of PPE usage on 39 respondents obtained from the of observations at the 1st and 2nd hours of the Blow Molding, Maintenance and Injection Molding unit at PT ARPS, it is shown that $10.2 \%$ of respondents had good behavior related to compliance usage PPE, $46.2 \%$ of respondents had fair behavior related to compliance with PPE use, and $43.6 \%$ of respondents had poor behavior related to compliance with PPE use when working. From table 1, it can be seen that the majority of workers had fair behavior related to compliance in using PPE when working.

Table 1. Frequency Distribution of Activator Factors at PT ARPS in 2018

\begin{tabular}{cccc}
\hline Variable & Category & Amount & $\begin{array}{c}\text { Percentage } \\
(\%)\end{array}$ \\
\hline \multirow{2}{*}{ Knowledge } & Good & 38 & 97.4 \\
& Perception & 1 & 2.6 \\
\hline \multirow{2}{*}{ Perception } & Good & 25 & 64.1 \\
& Enough & 14 & 35.9 \\
\hline PPE & Good & 24 & 61.5 \\
Regulations & Enough & 15 & 38.5 \\
\hline
\end{tabular}

Tabel 2. Frequency Distribution of Safety Behavior Factors Related to Compliance with the use of PPE in the Technician Work of the Blow Molding, Maintenance and Injection Molding Section at PT ARPS in 2018

\begin{tabular}{ccc}
\hline Category & Total & Percentage (\%) \\
\hline Good & 4 & 10.2 \\
Fair & 18 & 46.2 \\
Poor & 17 & 43.6 \\
\hline
\end{tabular}


Table 4. Cross Tabulation Between Perception and Safety Behavior Safety Behavior Related to Compliance with the Use of PPE at PT ARPS in 2018

\begin{tabular}{|c|c|c|c|c|c|c|c|c|c|}
\hline \multirow{3}{*}{ Knowledge } & \multicolumn{6}{|c|}{ Safety Behaviour } & \multirow{2}{*}{\multicolumn{2}{|c|}{ Total }} & \multirow{3}{*}{$\begin{array}{l}\text { Cooficient } \\
\text { Correlation }\end{array}$} \\
\hline & \multicolumn{2}{|c|}{ Good } & \multicolumn{2}{|c|}{ Fair } & \multicolumn{2}{|c|}{ Poor } & & & \\
\hline & $\mathbf{n}$ & $\%$ & n & $\%$ & $\mathbf{n}$ & $\%$ & $\mathbf{N}$ & $\%$ & \\
\hline Good & 0 & 0 & 1 & 100 & 0 & 0 & 1 & 100 & 0104 \\
\hline Fair & 4 & 10.5 & 17 & 44.7 & 17 & 44.7 & 38 & 100 & -0.104 \\
\hline
\end{tabular}

Table 3. Cross Tabulation of Occupational Health and Safety Knowledge with Safety Behavior Related to Compliance with the Use of PPE at PT ARPS in 2018

\begin{tabular}{|c|c|c|c|c|c|c|c|c|c|}
\hline \multirow{3}{*}{ Perception } & \multicolumn{6}{|c|}{ Safety Behaviour } & \multirow{2}{*}{\multicolumn{2}{|c|}{ Total }} & \multirow{3}{*}{$\begin{array}{l}\text { Cooficient } \\
\text { Correlation }\end{array}$} \\
\hline & \multicolumn{2}{|c|}{ Good } & \multicolumn{2}{|c|}{ Fair } & \multicolumn{2}{|c|}{ Poor } & & & \\
\hline & n & $\%$ & $\mathbf{n}$ & $\%$ & $\mathbf{n}$ & $\%$ & $\mathbf{N}$ & $\%$ & \\
\hline Good & 3 & 12.0 & 12 & 48.0 & 10 & 40.0 & 25 & 64.1 & \multirow{2}{*}{0.108} \\
\hline Fair & 1 & 7.1 & 6 & 42.9 & 7 & 50 & 14 & 35.9 & \\
\hline
\end{tabular}

\section{Knowledge}

Based on the data distribution in 2018 between OHS knowledge and safety behavior regarded compliance with PPE, it is shown that almost all workers, totalling 38 workers had fair knowledge of OHS. Of this number, the level of safety behavior of workers towards compliance with the use of PPE shared a similar number between fair and poor categories, comprising 17 people each. Meanwhile, based on the data, only 1 person had good knowledge of OHS and 1 person had fair safety behavior.

The analysis of the study shows that the correlation coefficient between the OHS knowledge variable and the Safety Behavior variable regarding compliance with PPE use -was 0.104. Based on the value of the correlation coefficient, it shows the relationship between the OHS knowledge variable and the Safety Behavior variable, whichhad a very weak relationship with a negative relationship. Workers with better levels of OHS knowledge would have a tendency for the level of safety behavior to decrease.

The results of the study illustrate that almost all respondents in the study had a good level of knowledge, but this condition is not matched by the level of safety behavior towards compliance behaviors of using PPE in accordance with SOP. In other words, the level of labor knowledge did not affect the workforce to take action in accordance with SOP.

\section{Perceptions}

Based on the distribution of data between perceptions and safety behaviors related to compliance with PPE, it is shown that the majority of workers totalling 25 workers had good perceptions about the risk of accidents and the danger of not using a good PPE. Of this number, 12 workers had a fair level of safety behavior regarding PPE use compliance, 10 workers had a poor level of safety behaviour and the rest had a good level of safety behavior. Meanwhile, 14 workers had fair perception about the risk of accidents and the dangers of not using PPE. Of this number, 7 workers had a poor level of safety behavior level regarding compliance with the use of, 6 workers had a fair level, and only 1 person had a good level of safety behaviour.

The results of the research analysis show that the correlation coefficient between the variable perception of the risk of accidents and the danger of not using PPE on workers with the safety behavior variable regarding compliance with PPE use was 0.108 . Based on the value of the correlation coefficient, it can be seen that there was a very weak correlation with the direction of a positive correlation.

The results of the study illustrate that workers with higher levels of perception about the risk of accidents and the danger of not using PPE would have a tendency to have a fair level of safety behavior. The results of the study illustrate that the majority of workers had a good level of perception, and this is balanced with workforce efforts to improve compliance behavior using PPE according to the SOP. In other words, the high level of workers' perception of PPE as well as the risk of hazards in the workplace could influence the workers to take actions according to SOP. 
Table 5. Cross Tabulation between PPE Regulations and Safety Behavior Related to Compliance with the use of PPE at PT ARPS in 2018

\begin{tabular}{|c|c|c|c|c|c|c|c|c|c|}
\hline \multirow{3}{*}{$\begin{array}{llr}\mathbf{P} & \mathbf{P} \quad \text { E } \\
\text { Regulations }\end{array}$} & \multicolumn{6}{|c|}{ Safety Behaviour } & \multirow{2}{*}{\multicolumn{2}{|c|}{ Total }} & \multirow{3}{*}{$\begin{array}{l}\text { Cooficien } 1 \\
\text { Correlation }\end{array}$} \\
\hline & \multicolumn{2}{|c|}{ Good } & \multicolumn{2}{|c|}{ Fair } & \multicolumn{2}{|c|}{ Poor } & & & \\
\hline & $\mathbf{n}$ & $\%$ & $\mathbf{n}$ & $\%$ & $\mathbf{n}$ & $\%$ & $\mathbf{N}$ & $\%$ & \\
\hline Good & 2 & 8.3 & 10 & 41.7 & 12 & 50 & 24 & 100 & 0166 \\
\hline Fair & 2 & 13.3 & 8 & 53.3 & 5 & 33.4 & 15 & 100 & -0.100 \\
\hline
\end{tabular}

\section{PPE Regulation}

Based on Table 5, the distribution data between PPE regulations and safety behavior related to compliance with PPE show that most of the workforce totalling 24 workers had a good opinion about company regulations in supporting safety behavior compliance with the use of PPE . Of this number, 12 workers had a poor level of safety behavior, 10 workers had a fair level and 2 workers had a good level of safety behavior conditions. Meanwhile, 15 workers had a fair opinion on company regulations in support of safety behavior in compliance with the use of PPE. Out of this number, there were 8 workers who had fair level of safety behavior, 5 workers had a poor level and 2 workers had a good level of safety behavior.

Analysis of the study show that the correlation coefficient between PPE regulatory variable with safety behavior variable regarding compliance with PPE use was -0.166 . Based on the value of the correlation coefficient, it can be said that there was a very weak relationship between the PPE regulation variable and the safety behavior variable regarding compliance with the use of PPE with a negative relationship direction. Workers with an increasingly good level of opinion regarding the rules of the use of PPE in the company would have a tendency for the poor level of safety behavior. Thus, it can be illustrated that some workers have already had a good level of opinion about PPE regulations with no offset behavior of compliance with the use of PPE in accordance with SOP.

\section{DISCUSSION}

\section{Activator Factor Component}

Application of behavior based safety in a company is certainly based on a particular cause, as happened at PT. ARPS. Based on the results of direct observations of workers, the sudy found that there were still workers who did unsafe actions due to a lack of knowledge about worker safety, whichcould lead to accidents. The unsafe behavior that was mostly done by workers when doing their work was they were not compliant in the use of Personal Protective Equipment (PPE) and neglected the importance of using PPE that had been recommended by the company. According to Skowron-grabowska and Sobociński (2018), Behavior-Based Safety (BBS) is a general approach to safety management, which sees the main cause of an accident as unsafe behavior carried out by someone. Thus, integrating behavior based safety programs can be the key to success in achieving program goals. This is in line with research by Ningsih and Wahyudiono (2013) which states that the lack of management roles is due to the lack of integration of behavior based safety (BBS) programs implemented in occupational safety and health management. This will have an impact that can be felt by workers, in accordance with the results of observations that indicate labor safe behavior work is still insuffient and lacking.

Many approaches can be taken to implement a behavior based safety program, one of which is by using the $\mathrm{ABC}$ model. $\mathrm{ABC}$ Theory defines that human behavior is influenced by 3 factors namely Activator, Behavior, and Consequence (ABC). This research discusses several factors that influence the activator of the behavior of PPE use, namely knowledge, perceptions and regulations regarding PPE in PT. APRS. Behavior is something that someone does that can be observed, measured, and can be done repeatedly. Behavior can also be interpreted as an action (Bicard and Bicard, 2012).

PPE are tools designed to protect employees from serious injury or illness in the workplace caused by contact with chemicals, radiology, or physical, electrical, mechanical hazards in theworkplaces (Aguwa, Arinze-Onyia and Ndu, 2016). The components of PPE are very diverse. Some studies specify one PPE element (for example, respirators, gloves, and masks) but other components are not explained in detail (for example, barrier techniques 
and protective clothing) (Hersi et al., 2015). From the results of direct observation of workers who used PPE on the blow molding, maintenance and injection molding unit at PT ARPS, it was found that $46.2 \%$ of workers had good behavior related to compliance with the use of PPE when working, but $43.6 \%$ of workers had poor behavior related to compliance with PPE when working. The above research results are not in line with research by Sari (2014) who conducted research in the Production Unit III of PT. Petrokimia Gresik. In her study, it is shown that the majority of workers were compliant in using personal protective equipment when working (79.3\%), while only a small portion of the workforce did not use PPE when working (20.7\%). This could happen if the company is not serious in committing the policy regarding compliance with the use of PPE. The company must also provide support to the workforce by providing training in order to establish a good attitude about compliance with the use of PPE. According to Bisen and Priya (2010), two important elements for creating cultural change in an organization are work training and support. Therefore, to form a culture of compliance using PPE, companies need to involve workforce support and carry out training according to needs. Workforce support for PPE policy is very important because labor is the main actor in compliance behavior of using PPE.

\section{Knowledge}

The first activator factor component is the level of knowledge. Knowledge is the dominant factor in influencing someone before acting. Behavior will last longer if it is based on knowledge, whereas behavior which is not based on knowledge will not last long (Notoadmodjo, 2007). Knowledge is the result of events that have been felt by someone, so they know a particular situation. Meanwhile, sensing can be done using the human senses such as vision, smell, taste, hearing (Hendrawan, 2019).

In this study, the intended knowledge is about everything that is known by workers about OHS in general, the definition of PPE, the benefits of using PPE, time to use PPE and the terms of the use of PPE. The results show that the relationship of knowledge variables with safety behavior had a very weak relationship with the direction of a negative relationship. Workers with better levels of OHS knowledge would have a tendency for the level of Safety Behavior to decrease. The results of the study illustrate that all research respondents had a fair level of knowledge, but this is not matched by the compliance behavior of the use of PPE that is in accordance with SOP. In other words, the high level of knowledge of workers does not make workers to take action in accordance with SOP. Knowledge should be able to be the underlying information for behavior to occur. It is also not in accordance with research conducted by Nasrullah and Suwandi (2014) stating that $76.0 \%$ of respondents who had a good level of safe behavior knowledge also had good level of safe behavior attitudes.

The results of this study are in line with the results of research conducted by Gultom and Widajati,(2016) stating that there was a strong relationship between knowledge and poor safety. Because knowledge is one's response to the stimulus in the form of covert or closed state and cannot be clearly observed, so it cannot judge actions and behaviors that can be observed directly by observers. This is also supported by results of research done by Andriyanto (2017) stating that workers'knowledge of OHS had a strong relationship with compliance behavior of the use of PPE.

This is indeed natural to occur as expressed by Anam (2015), that an increase in science does not always cause changes in behavior, but a positive relationship between two variables. A mistake or violation can occur because someone knows what to do but decides not to do it (Prabasworo, 2016). Violations, which in this case are related to safety behavior regarding compliance with the use of PPE, in facthappen because someone already knows what to do but decides not to do it. This is because someone considers violations to be legal or natural, and violations are easy to do without any severe consequences.

\section{Perception}

Perception is the earliest stage of a series of processes for processing information. Perception is a process of using knowledge that has been stored in a person's memory, which is laterused to detect or obtain and interpret a stimulus (stimuli) received by sensory organs such as eyes, ears, and nose (Rehalat, 2014). It can be concluded that perception is the process of understanding information through human sensory systems. Perception is very dependent on one's point of view of an object. The appearance of a perception depends on an individual's ability to respond to a stimulus. This causes perceptions between one individual with another individual to be different; in other words, how to interpret something 
that is seen is not necessarily the same between individuals. Perception is very influential on changes in behavior in a person. Perception can be defined an individual process in organizing and interpreting their sense or impressions of their environment (Sialagan, 2008). The perception intended in this study is about the opinion of workers on the risk of accidents and the risk of harm from not using PPE in the workplace. This perception provides a basis for someone to behave according to what they perceive.

The results showthat the relationship between perception variables with safety behavior had a weak relationship with a positive relationship direction. Workers with a higher level of perception about the risk of accidents and the danger of not using PPE would have a tendency for an increased level of safety behavior. About $12 \%$ of workers were in the good category, $48 \%$ of workers were in the fair category, and $40 \%$ of workers were in the poor category. The results of the study illustrate that the majority of workers had a fair level of perception, and this result is in line with the level of compliance behavior of PPE usage according to SOP for workers. In other words, the high level of worker perception about PPE and the risk of hazards at work can encourage workers to take action in accordance with SOP. This is supported by an explanation of Nurlaela (2014) stating that a person's behavior is determined and influenced by several factors, including subjective perception, selective attention, characteristics of stimuli, individual values and needs, and experience. Positive employee perceptions and a proper understanding of occupational safety and health are critical determinants of the progress of the implementation of occupational safety and health programs.

Results of research conducted by Sari (2014) also illustrates that there was a strong relationship between the level of employee perception with Safety Behavior, with the direction of a positive relationship. The results of her research found that as many as $91.3 \%$ of respondents who had a positive perception of the risk of accidents and hazards tended to have good safety behavior when working. This can occur because when workers have the right perception of the hazards and risks of accidents in the workplace, it will increase workers' safety behavior to avoid the hazards and risks of work accidents as they perceive. Thus, it can be concluded that perception is very important because perception is a person's initial stage in concluding information.
Mistakes in interpreting the perception will lead to a dangerous state and dangerous behavior.

\section{PPE Regulations}

Regulation is a procedure carried out by a particular party to bring order and harmony with the needs of a particular party. Rules are also useful for mental and psychological development for those who obey them as well as foster respect and better individual (Rahman, 2016). Policy is a factor that reinforces the occurrence of a behavior. This is in accordance with the opinions that put the policy as a part of the environment in the safety triad so that this opinion implies that the policy is a component of the environment that can affect behavior (Julaikah, 2019). Regulations are laws approved by the government, and the law in the workplace can be made under the OHS by following and adjusting proposals or regulations made by the company (Health and Safety Executive, 1999). The regulations referred to in this study are related to the opinions of workers regarding company policies in supporting workforce safe behavior (use of PPE). Based on the results of interviews with Safety Managers and observations, PT ARPS has already had policies and regulations related to OHS in the workplace in general, regulations regarding the use of PPE in the work area and supported by overall work procedures. The regulation is made in the written form and there are some posted in the work area. This in line with the statement by Roughton and Mercurio (2002) stating that safety regulations will be more effective if they are made in written form.

Based on the results of the study, around $61.5 \%$ of workers stated that regulations of OHS, especially regarding PPE in the company were classified as good. This means that most workers had known and understood safety regulations made by the management. The research results also showed that the relationship of PPE regulatory variables with safety behavior had a very weak relationship with a negative relationship direction. Workers with a good level of opinion regarding the rules of the use of PPE in the company had a tendency of decreasing safety behavior levels. Thus, it can be illustrated that some workers have already had a good level of opinion about PPE regulations with no offset behavior in compliance with the use of PPE accordance with SOP. In other words, the high level of employee opinion regarding PPE regulations in companies does not support workers in taking action in accordance with SOP. 
This research is in line with what was done by Suyono and Nawawinetu (2010) which showed that from the results of the Continuity Correction statistical test between the regulatory variables and OHS procedures with the behavior of OHS there was no relationship between the two variables. Similar results were also stated by Nurdiani and Krianto (2019). In their study using the regulatory variable, $68.0 \%$ of respondents said that the regulation makes them comply with the use of PPE, while in the condition where there was no regulation, it was found that $89.5 \%$ obeyed the use of PPE. In short, the results show that workers with regulations had a smaller value than workers who had no rules. This is in line with the statement by Notoatmodjo (2003) that enacting a strategy to improve safety behavior using regulations does produce rapid behavioral changes, but these changes will not necessarily last long because behavioral changes that occur are not or have not been based on self-awareness.

\section{CONCLUSION}

Based on the results of the study, it can be concluded that the workforce behaved poorly in using PPE in the workplace. Workers in the Blow Molding, Maintenance and Injection Molding unit had a fair level of knowledge, and workers had a fair level of perception regarding compliance with the use of PPE. Moreover,workers had a fair level of ability to company regulations in supporting safety behavior related to compliance with the use of PPE at PT APRS.

\section{ACKNOWLEDGEMENTS}

Our thanks go to Allah SWT. Moreover, Our current position and condition would not have been possible without the presence of our family as this research was also conducted using personal funding thanks to big family and bestfriends who have supported us up to the current position..

\section{REFERENCES}

Aguwa, E., Arinze-Onyia, S. U. and Ndu, A. (2016) 'Use of Personal Protective Equipment among Health Workers in a Tertiary Health Institution, South East Nigeria: Pre-Ebola Period', International Journal of Health Sciences and Research, 6(8), pp. 12-18.
Andriyanto, M. R. (2017) 'Hubungan Predisposing Factor dengan Perilaku Penggunaan Apd pada Pekerja Unit Produksi I PT Petrokimia Gresik', The Indonesian Journal of Occupational Safety and Health, 6(1), pp. 37-47.

Barizqi, I. N. (2015) Hubungan Antara Kepatuhan Penggunaan APD Dengan Kejadian Kecelakaan Kerja Pada Pekerja Bangunan PT. Adhi Karya Tbk Proyek Rumah Sakit Telogorejo Semarang. Undergraduate Thesis . Semarang: Faculty of Sport Science, Universitas Negeri Semarang.

Bicard, S. C. and Bicard, D. F (2012) Defining Behavior. Montgomer City: The Iris Center.

Bisen, V. and Priya (2010) Industrial Psychology. New Delhi: New Age International.

Geller, E. S. (2005) 'Behavior-Based Safety and Occupational Risk Managemet', Journal Behavior Modification, 29(3), pp. 539-561.

Geller, E. S. (2006) 'People-Based Safety An Evolution of Behavior-Based Safety for Greater Effectiveness', Virginia Polytechnic Institute and State University, (1).

Gultom, G. O. and Widajati, N. (2016) 'Hubungan Personal Factor Dengan Safety Behaviour Pekerja Confined Space PT. X', Jurnal Ilmiah Keperawatan, 2(2), pp. 51-56.

Hashim, M. A. S and May, E. J. (2018) 'Effectiveness of Personal Protective Equipment ( PPE ) at Construction Site', Inti Journal, 1(12), pp. 2600-7920.

Health and Safety Executive (1999) Health and Safety Regulation. Europa.

Hendrawan, M. R. (2019) Manajemen Pengetahuan Konsep dan Praktik Berpengetahuan pada Organisasi Pembelajaran. Malang: Tim Ub Press.

Hersi, M. et al. (2015) 'Effectiveness of Personal Protective Equipment for Healthcare Workers Caring for Patients with Filovirus Disease : A Rapid Review', Plos One, 10(10), pp. 1-17.

International Labour Organization (2018) Meningkatkan Keselamatan dan Kesehatan Pekerja Muda. Jakarta: Organisasi Perburuhan Internasional 2018.

Julaikah (2019) 'Analisa Perilaku Aman Pekerja UPT Balai Yasa dengan Pendekatan Model Perilaku ABC', Jurnal Ilmiah Ilmu Keperawatan dan Ilmu Kesehatan Masyarakat, 14(1), pp. 90-1 02.

Ningsih, A. R. and Wahyudiono, Y. D. A. (2013) 'Evaluasi Pelaksanaan Behavior Based Safety Pada Program Stop dalam Membentuk Perilaku Aman Tenaga Kerja di PT X Tahun 2013', The 
Indonesian Journal of Occupational Safety and Health, 2(1), pp. 35-44.

Notoadmodjo, S. (2007) Promosi Kesehatan dan Ilmu Perilaku. Jakarta: Rineka Cipta.

Notoatmodjo, S. (2003) Pendidikan dan Perilaku Kesehatan. Jakarta: Rineka Cipta.

Nurdiani, C. U. and Krianto, T. (2019) 'Kepatuhan penggunaan alat pelindung diri (APD) di laboratorium pada Mahasiswa Prodi Diploma Analis Kesehatan Universitas MH Thamrin', Jurnal Ilmiah Kesehatan, 11(2), pp. 88-93.

Prabasworo, N. N. (2016) Hubungan iklim Keselamatan Kerja dengan Kepatuhan pada Peraturan Keselamatan Oleh Perawat di Rumah Sakit. Undergraduate Thesis. Malang: Faculty of Psycology, Universitas Muhammadiyah Malang.

Rahman, S. H.(2016) Implementasi Peraturan Sekolah dalam Meningkatkan Kedisiplinan Guru dan Siswa (Studi Multisitus di Madrasah Ibtida'iyah (MI) Darul Ulum Beraim dan Madrasah Ibtida'iyah (MI) Mambaul Khair NW Bertais). Thesis. Malang: Program Megister Pendidikan Guru Madarasah Ibtida'iyah, Universitas Islam Negeri Maulana Malik Ibrahim.

Rehalat, A. (2014) 'Model Pembelajaran Pemrosesan Informasi', Jurnal Pendidikan Ilmu Sosial, 23(2), pp. $1-11$.

Roughton, J. and Mercurio, J. (2002) Developing an Effective Safety Culture: A Leadership Approach. Georgia: Butterworth-Heinemann.
Sari, D. F. P. (2014) Faktor yang Berhubungan dengan Penggunaan Alat Pelindung Diri (APD) di Unit Produksi III PT. Petrokimia Gresik. Undergraduata Thesis. Surabaya: Faculty of Public Health, Universitas Airlangga.

Sialagan, T. R. (2008) Analisis Faktor-Faktor Yang Berkontribusi Pada Perilaku Aman di PT EGS Indonesia Tahun 2008. Thesis. Depok: Faculty of Public Health, Universitas Indonesia.

Skowron-grabowska, B. and Sobociński, M. D. (2018) 'Behaviour Based Safety ( BBS ) - Advantages and Criticism', Porduction Engineering Archives, (11), pp. 12-15.

Sugiyono (2017) Metode Penelitian Kuantitatif, Kualitatif, dan $R \& D$. Bandung: Alfabeta,CV.

Tanko, B. L. and Anigbogu, N. (2012) 'The Use Of Personal Protective Equipment ( PPE ) On Construction site in Nigeria', Proceedings 4th WABER Conference. pp 1341-1348

Uzun, M. et al. (2018) 'Hierarchy of Control Measures for Common Construction Activities : A Field Hierarchy of Control Measures for Common Construction Activities : A Field Study', 5th international Project and Construction Management Conference (IPCMC2018), (September).

Wang, M. et al. (2018) 'Relations between Safety Climate, Awareness, and Behavior in the Chinese Construction Industry : A Hierarchical Linear Investigation', Advances in Civil Engineering, 2018(65), pp. 1-8. 